\title{
A New Approach of Extraction of $\alpha$-Amylase/trypsin Inhibitors from Wheat (Triticum aestivum L.), Based on Optimization Using Plackett-Burman and Box-Behnken Designs
}

\author{
Sorel Tchewonpi Sagu ${ }^{1}$, Gerd Huschek ${ }^{2}$, Josephine Bönick ${ }^{2}$, Thomas Homann ${ }^{1}$ and \\ Harshadrai M. Rawel ${ }^{1, *(1)}$ \\ 1 University of Potsdam, Institute of Nutritional Science, Arthur-Scheunert-Allee 114-116, 14558 Nuthetal, \\ Potsdam, Germany; sorelsagu@uni-potsdam.de (S.T.S.); homann@uni-potsdam.de (T.H.) \\ 2 IGV-Institut für Getreideverarbeitung $\mathrm{GmbH}$, Arthur-Scheunert-Allee 40/41, D-14558 Nuthetal OT \\ Bergholz-Rehbrücke, Germany; gerd.huschek@igv-gmbh.de (G.H.); Josephine.Boenick@igv-gmbh.de (J.B.) \\ * Correspondence: rawel@uni-potsdam.de; Tel.: +49-33200-88-5525/5578
}

Received: 20 August 2019; Accepted: 3 October 2019; Published: 5 October 2019

\begin{abstract}
Wheat is one of the most consumed foods in the world and unfortunately causes allergic reactions which have important health effects. The $\alpha$-amylase/trypsin inhibitors (ATIs) have been identified as potentially allergen components of wheat. Due to a lack of data on optimization of ATI extraction, a new wheat ATIs extraction approach combining solvent extraction and selective precipitation is proposed in this work. Two types of wheat cultivars (Triticum aestivum L.), Julius and Ponticus were used and parameters such as solvent type, extraction time, temperature, stirring speed, salt type, salt concentration, buffer $\mathrm{pH}$ and centrifugation speed were analyzed using the Plackett-Burman design. Salt concentration, extraction time and $\mathrm{pH}$ appeared to have significant effects on the recovery of ATIs $(p<0.01)$. In both wheat cultivars, Julius and Ponticus, ammonium sulfate substantially reduced protein concentration and inhibition of amylase activity (IAA) compared to sodium chloride. The optimal conditions with desirability levels of 0.94 and 0.91 according to the Doehlert design were: salt concentrations of 1.67 and $1.22 \mathrm{M}$, extraction times of 53 and $118 \mathrm{~min}$, and $\mathrm{pHs}$ of 7.1 and 7.9 for Julius and Ponticus, respectively. The corresponding responses were: protein concentrations of 0.31 and $0.35 \mathrm{mg}$ and IAAs of 91.6 and 83.3\%. Electrophoresis and MALDI-TOF/MS analysis showed that the extracted ATIs masses were between 10 and $20 \mathrm{kDa}$. Based on the initial LC-MS/MS analysis, up to 10 individual ATIs were identified in the extracted proteins under the optimal conditions. The positive implication of the present study lies in the quick assessment of their content in different varieties especially while considering their allergenic potential.
\end{abstract}

Keywords: wheat; $\alpha$-amylase/trypsin inhibitors; extraction; Plackett-Burman design; Doehlert design; SDS-PAGE; MALDI-TOF/MS; LC-MS/MS

\section{Introduction}

Wheat has become one of the most important foods in the world. Its growing consumption has led to an increase in allergies such as gluten intolerance, celiac disease and IgE-mediated allergies (including respiratory immune responses, especially for bakers) that affects about $0.4-2 \%$ of the general population, depending on the age and region [1-3]. A food allergy is described as an adverse health effect involving immunological mechanisms (allergic reactions) that can be induced in sensitized children and adults following dietary exposure to relevant allergens in foods [4]. These allergens are usually proteins, but sometimes chemicals such as haptens have also been reported [5]. Gluten has long 
been pointed out as being the main culprit [6-9]. Newer studies have explored other wheat compounds that may also cause such problems and one of these candidates are $\alpha$-amylase/trypsin inhibitors (ATIs). ATIs are bifunctional biological substances that bind to $\alpha$-amylase and trypsin making them inactive. They can inhibit bacterial amylases, insect amylase and mammalian amylase, and it has been further observed that some wheat ATIs strongly inhibits insect $\alpha$-amylases, but not necessarily mammalian $\alpha$-amylases [10]. Wheat ATIs generally contain five $\alpha$-helices arranged in up and down manner and are rich in cysteine residues forming disulfide bonds. Wheat ATIs 0.19 and 0.28 were among the first to structurally be described; the inhibitor 0.19 being a dimer of molecular weight $24 \mathrm{kDa}$ and the inhibitor 0.28 a monomer of molecular weight $12 \mathrm{kDa}$. [11]. Wheat ATIs were first studied in part because they played an important role in plant resistance to insects and microbial parasites [12] and also increasingly more recently because of their allergic effects [13-15].

Based on their differential solubility, wheat proteins can be classified into albumin and globulin, soluble in water or salt solutions, as well as gliadins (soluble in e.g., aqueous alcoholic solutions) and glutenins (in dilute acids/bases) remaining insoluble in water/salt solutions [16]. ATIs belong to the group of low-molecular weight salt-soluble proteins with masses ranging between 10 to $20 \mathrm{kD}$. As of September 2019, there were a total of 13 reviewed and two unreviewed wheat ATIs registered in the Uniprot online database (https:/www.uniprot.org/uniprot, as assessed on 09.09.2019). They are characterized by their solubility in mixtures of chloroform and methanol (CM) and for this reason were called CM proteins [17]. As much as CM mixtures, salts solutions are also used for extraction of ATIs. Ammonium sulfate and sodium chloride at low concentration have been preferentially used [13,14,18]. Other buffer solutions were also employed. Geisslitz, et al. [19] used ammonium bicarbonate buffer to extract ATIs from 38 different products, including wheat, and fast-performance liquid chromatography was involved to complete the purification process. A number of studies have addressed the diversity of wheat ATIs by qualitative and quantitative characterization using HPLC fractionation and mass spectrometry tools. Feng et al. [12] analyzed $\alpha$-amylase inhibitors from wheat flours by preparative, reversed-phase high performance liquid chromatography. Geisslitz et al. [19] used Targeted LC-MS/MS to quantify ATIs from different varieties of cereals, including wheat. Tundo, et al. [20] attempted to produce pure three ATIs considered major wheat allergens, named CM3, CM16 and 0.28, using isolated mRNA and cDNAs for heterologous expression.

It emerges from this review that there is a lack of data on optimization of ATI extraction. Empirical screening is generally used, which implies the use of numerous set of parameters until the appropriate conditions are achieved. This method is very expensive; it requires a great number of experiments and much time [21]. The establishment of a simple, cheaper and optimal method of ATIs extraction and purification remains a challenge. Design of experiments (DOE) is a systematic approach that uses mathematical tools to define the importance of specific processing variables and how to control them to optimize system performance while maximizing properties. DOE can generate the required information with a minimum of experimentation, using limited experiments, specific experimental conditions and mathematical analysis to predict the response at any point of the experimental domain [22]. In this work, a new approach to extract and purify ATIs from wheat in two steps is proposed. It combines the classical CM extraction with the selective precipitation using salt solutions. Different parameters are tested with the Plackett-Burman design and optimization is realized using Doehlert design.

\section{Results and Discussion}

\subsection{Screening with Plackett Burman Design}

Protein concentration and inhibition of amylase activity were evaluated with the Plackett Burman design and the results are presented in Table 1. Changes in protein concentration ranging from $0.16 \pm 0.01$ to $0.63 \pm 0.04 \mathrm{mg} / \mathrm{mL}$ and inhibition of amylase activity (IAA) from $17.6 \pm 0.9$ up to $90.2 \pm$ $0.7 \%$ were observed using Julius. About $0.16 \pm 0.03$ to $0.61 \pm 0.04 \mathrm{mg} / \mathrm{mL}$ of the protein concentration, and $26.6 \pm 1.6$ to $90.3 \pm 2.7 \%$ of IAA were registered with Ponticus. 
Table 1. Plackett-Burman design presenting the eleven factors and the two corresponding experimental responses for the Julius and Ponticus cultivars.

\begin{tabular}{|c|c|c|c|c|c|c|c|c|c|c|c|c|c|c|c|}
\hline \multirow{3}{*}{$\mathrm{Nb}$} & \multirow{2}{*}{\multicolumn{11}{|c|}{ Parameters }} & \multicolumn{4}{|c|}{ Experimental Responses } \\
\hline & & & & & & & & & & & & \multicolumn{2}{|c|}{ Julius } & \multicolumn{2}{|c|}{ Ponticus } \\
\hline & $X_{1}$ & $X_{2}$ & $X_{3}$ & $\mathrm{X}_{4}$ & $X_{5}$ & $X_{6}$ & $X_{7}$ & $X_{8}$ & $X_{9}$ & $X_{10}$ & $X_{11}$ & $\begin{array}{l}\text { Protein conc. } \\
(\mathrm{mg} / \mathrm{mL})\end{array}$ & IAA (\%) & $\begin{array}{l}\text { Protein conc. } \\
(\mathrm{mg} / \mathrm{mL})\end{array}$ & IAA (\%) \\
\hline 1 & $\mathrm{D} / \mathrm{M}$ & $2: 1$ & $125: 1$ & 50 & 4 & 60 & 30 & 9 & $(\mathrm{NH} 4)_{2} \mathrm{SO}_{4}$ & 1 & 10000 & $0.22 \pm 0.03$ & $29.3 \pm 1.6$ & $0.27 \pm 0.03$ & $26.6 \pm 1.6$ \\
\hline 2 & $\mathrm{D} / \mathrm{M}$ & $1: 1$ & $250: 1$ & 0 & 4 & 60 & 80 & 9 & $(\mathrm{NH} 4)_{2} \mathrm{SO}_{4}$ & 0.5 & 12000 & $0.31 \pm 0.01$ & $63.3 \pm 2.2$ & $0.27 \pm 0.01$ & $65.0 \pm 3.0$ \\
\hline 3 & $\mathrm{C} / \mathrm{M}$ & $2: 1$ & $250: 1$ & 50 & 4 & 180 & 80 & 8 & $(\mathrm{NH} 4)_{2} \mathrm{SO}_{4}$ & 0.5 & 10000 & $0.20 \pm 0.04$ & $61.9 \pm 5.3$ & $0.24 \pm 0.08$ & $29.0 \pm 1.4$ \\
\hline 4 & $\mathrm{D} / \mathrm{M}$ & $2: 1$ & 250:1 & 0 & 25 & 180 & 30 & 9 & $\mathrm{NaCl}$ & 0.5 & 10000 & $0.63 \pm 0.04$ & $87.8 \pm 3.2$ & $0.61 \pm 0.04$ & $90.3 \pm 2.7$ \\
\hline 5 & $\mathrm{D} / \mathrm{M}$ & $1: 1$ & 250:1 & 50 & 4 & 180 & 30 & 8 & $\mathrm{NaCl}$ & 1 & 12000 & $0.49 \pm 0.01$ & $90.2 \pm 0.7$ & $0.52 \pm 0.01$ & $62.0 \pm 2.6$ \\
\hline 6 & $\mathrm{C} / \mathrm{M}$ & $1: 1$ & $250: 1$ & 50 & 25 & 60 & 80 & 9 & $\mathrm{NaCl}$ & 1 & 10000 & $0.56 \pm 0.05$ & $89.8 \pm 2.4$ & $0.40 \pm 0.03$ & $87.0 \pm 3.5$ \\
\hline 7 & $\mathrm{C} / \mathrm{M}$ & $2: 1$ & $250: 1$ & 0 & 25 & 60 & 30 & 8 & $(\mathrm{NH} 4)_{2} \mathrm{SO}_{4}$ & 1 & 12000 & $0.18 \pm 0.01$ & $17.6 \pm 0.9$ & $0.16 \pm 0.03$ & $35.7 \pm 1.0$ \\
\hline 8 & $\mathrm{C} / \mathrm{M}$ & $1: 1$ & $125: 1$ & 50 & 25 & 180 & 30 & 9 & $(\mathrm{NH} 4)_{2} \mathrm{SO}_{4}$ & 0.5 & 12000 & $0.32 \pm 0.01$ & $56.0 \pm 1.7$ & $0.35 \pm 0.03$ & $39.5 \pm 0.9$ \\
\hline 9 & $\mathrm{C} / \mathrm{M}$ & $2: 1$ & $125: 1$ & 0 & 4 & 180 & 80 & 9 & $\mathrm{NaCl}$ & 1 & 12000 & $0.50 \pm 0.02$ & $85.1 \pm 5.2$ & $0.53 \pm 0.05$ & $83.4 \pm 1.7$ \\
\hline 10 & $\mathrm{D} / \mathrm{M}$ & $1: 1$ & $125: 1$ & 0 & 25 & 180 & 80 & 8 & $(\mathrm{NH} 4)_{2} \mathrm{SO}_{4}$ & 1 & 10000 & $0.16 \pm 0.01$ & $29.8 \pm 4.1$ & $0.21 \pm 0.02$ & $33.8 \pm 1.9$ \\
\hline 11 & $\mathrm{C} / \mathrm{M}$ & $1: 1$ & $125: 1$ & 0 & 4 & 60 & 30 & 8 & $\mathrm{NaCl}$ & 0.5 & 10000 & $0.62 \pm 0.07$ & $78.7 \pm 2.5$ & $0.55 \pm 0.01$ & $87.3 \pm 2.7$ \\
\hline 12 & $\mathrm{D} / \mathrm{M}$ & $2: 1$ & $125: 1$ & 50 & 25 & 60 & 80 & 8 & $(\mathrm{NH} 4)_{2} \mathrm{SO}_{4}$ & 1 & 12000 & $0.23 \pm 0.02$ & $20.4 \pm 0.8$ & $0.19 \pm 0.01$ & $26.6 \pm 1.4$ \\
\hline
\end{tabular}

C: chloroform; D: dichloromethane; M: methanol; IAA: inhibition of amylase activity. With X1-the type of extraction solvent, X2 -the composition of solvents mixture in ratio, $\mathrm{X} 3$ - the ratio of sample/solvent, $\mathrm{X} 4$ - the concentration of Urea, X5-the extraction temperature, $\mathrm{X} 6$ - time of extraction, $\mathrm{X} 7$-stirring speed, X8-the $\mathrm{pH}$ of Tris buffer, $\mathrm{X} 9$-type of salt,

$\mathrm{X} 10$ - concentration of salt and X11—centrifugation speed. 


\subsubsection{Evaluation of Parameters Effects on the Extraction of ATIs}

Analysis of Plackett Burman design (PBD) experimental data was performed by calculating the coefficient of regression as well as the standard error and the statistical confidence level. The results are presented in Table S4 (Supplementary Data). It appears that the type of solvent mixture (X1), the composition of the solvent (X2) as well as the ratio of sample/solvent (X3) had no significant effect on the protein content and IAA as noted for Julius and Ponticus. These results show that dichloromethane can be used with the same performance as chloroform for carrying out ATIs extraction. Likewise, these results indicate that the ratios of chloroform/methanol or dichloromethane/methanol of 1:1 or 2:1 can be used without much difference in term of ATIs recovery. This corroborates the results showing that, although chloroform is considered to be a model hydrophobic polar solvent, dichloromethane can be used as a replacement for chloroform for the treatment of a large number of plant samples [23,24]. The use of mixtures of chloroform/methanol is a popular strategy used to extract highly hydrophobic proteins [25]. It is demonstrated that the $\mathrm{C} / \mathrm{M}$-soluble fractions from cereals esp. from wheat are enriched in proteins containing a high number of non-polar amino acids (49-59\% not counting cysteine and tryptophan) [26].

The stirring speed and extraction temperature were not overall significant, with partly effects on few responses (Table S4). The same results were observed for urea, except result of IAA with Ponticus sample which was significantly different. Urea is generally used to denature protein complexes $[27,28]$ and to reduce hydrophobic forces by providing an adequate environment for non-polar groups [29]. The ATIs being non-globular proteins, interactions of urea with hydrogen bonds or hydrophobic forces do not directly affect their stability in solution.

The negative sign of the coefficients of salt type and salt concentration indicates that increasing the values of these parameters had reduced the recovery of ATIs in solution. The clear understanding of salt effects on biological systems and in particular on interactions and phase behavior of proteins, what is meant by salting-out and salting-in, was always of great interest. It is well know that at low salt concentration, protein solubility generally increases ("salting-in") whereas "salting-out" is an important experimental means of isolating, breaking down and crystallizing proteins occurring at high salt concentrations [30]. Thus, the behavior of proteins in solution will be directly related to the concentration of salt present. As can be seen, increasing of salt concentration helped to significantly reduce the protein content while maintaining the inhibitory activity, showing a selective precipitation of proteins (Table S4). Moller et al. [21] suggested that this is largely due to electrostatic screening effects which decrease the effective repulsive electrostatic interaction of the charged proteins and thus selectively reduce their solubility in water. Analysis reveals that at the same concentration, ammonium sulfate significantly reduces more protein concentration compared to sodium chloride. Minimum values of protein concentration of $0.16 \pm 0.01$ and $0.18 \pm 0.01 \mathrm{mg} / \mathrm{mL}$ were obtained with ammonium sulfate at the concentration of $1 \mathrm{M}$ using Julius (Table 1). It is well established that at equal concentrations, the ionic strength of ammonium sulfate is greater than that of sodium chloride, which justifies the observed results. Similar results were observed with $\mathrm{pH}$. Table $\mathrm{S} 4$ show that $\mathrm{pH}$ had a significant influence on all experimental responses with $p$-value $<0.05$. The structural integrity of proteins and their stability in solution depend on several factors and $\mathrm{pH}$ is one of the most important one. Either high or low pHs are widely used to precipitate proteins [31-33].

\subsubsection{Selection of Parameters for Optimization}

Eleven parameters were screened by twelve trial runs using Julius and Ponticus as samples. Protein concentration and inhibition of amylase activity were used to evaluate the extraction process.

Based on the Pareto chart presented in Figure 1, parameters were classified according to their effects. It appeared that salt type, salt concentration, buffer $\mathrm{pH}$, and extraction time were the most significant parameters $(p<0.01)$ (see also Table S4, Supplementary Data). The standardized effect showed a negative role of ammonium sulfate on protein concentration and IAA. For this reason, sodium chloride was therefore chosen to be used as precipitation salt. The salt concentration had a negative 
effect and needed to be optimized. The same effect was observed with extraction time and buffer $\mathrm{pH}$. The efficiency of ATIs extraction and purification from wheat flour had to be increased by a lower salt concentration or a shorter extraction time. All these reasons led us to select the $\mathrm{pH}$, the salt concentration and the extraction time as parameters to be optimized. Other parameters that did not significantly affect the extraction process were set based on the statistical analysis and their individual effects. A 2:1 ratio mixture of chloroform/methanol was selected as extraction solvent. The samples/solvent ratio of 125:1 (mass/volume), the stirring speed of $30 \mathrm{rpm}$, the extraction temperature of $4{ }^{\circ} \mathrm{C}$ and $10,000 \times \mathrm{g}$ centrifugation speed of were chosen. Urea had no effect on ATIs extraction and was removed from the further optimization steps.

(a)

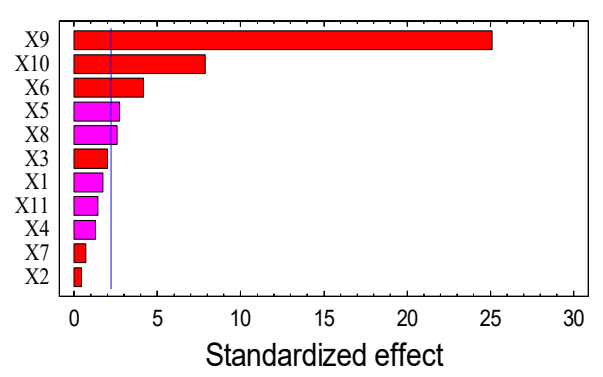

(b)

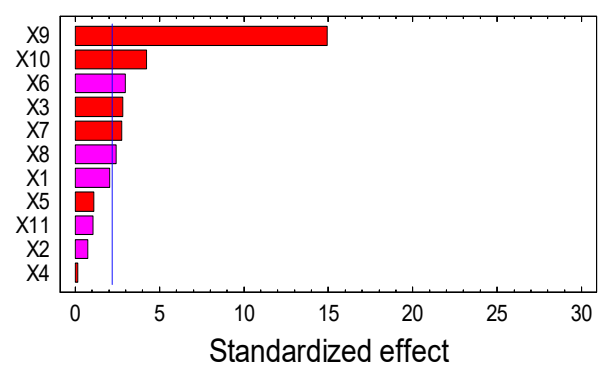

(c)

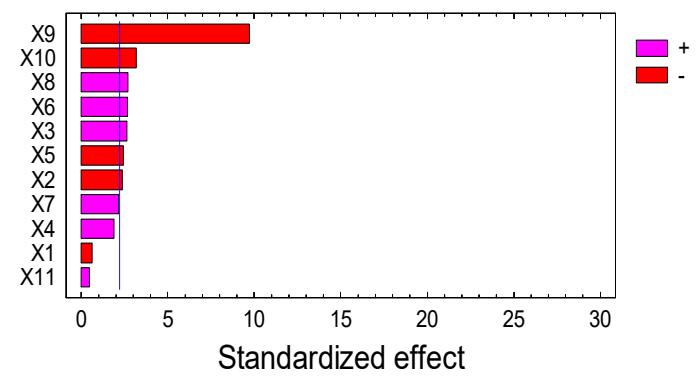

(d)

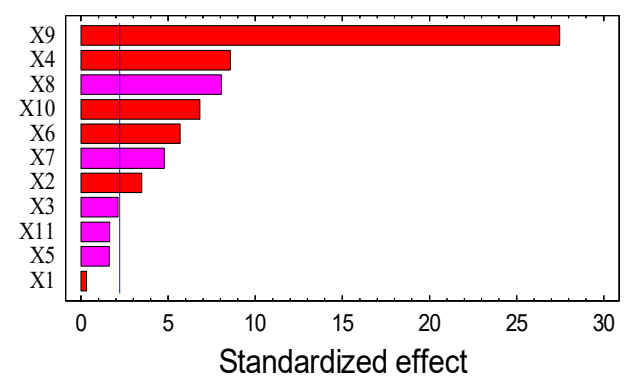

Figure 1. Standardized Pareto graph showing effect of the type of solvent, $\mathrm{X} 1$; the composition of solvents mixture, $\mathrm{X} 2$; the ratio of sample/solvent, $\mathrm{X} 3$; the concentration of Urea, $\mathrm{X} 4$; the extraction temperature, $X 5$; the extraction time, $X 6$; stirring speed, $X 7 ; \mathrm{pH}, \mathrm{X} 8$; type of salt, $X 9$; concentration of salt, $\mathrm{X} 10$; and centrifugation speed, $\mathrm{X} 11$ on: $(\mathbf{a}, \mathbf{b})$ concentration of protein and $(\mathbf{c}, \mathbf{d})$ inhibition of amylase activity for Julius and Ponticus, respectively. The blue vertical line indicates the limit of the standardized effect whose values are significantly different from zero at the $95.0 \%$ confidence level. The pink color shows that the parameter has a positive effect and the red color a negative effect on the experimental response.

\subsection{Optimization of Extraction Process}

\subsubsection{Evaluation of the Effect of Parameters on Protein Concentration in IAA}

Response surface methodology (RSM) with a Doehlert design (DD) was used to optimize the three most significant parameters: salt concentration, buffer $\mathrm{pH}$ and extraction time. Table 2 shows that the inhibition of trypsin activity was not substantial. Trends varied in total between $1.2 \pm 0.1$ and $6.6 \pm 0.9 \%$ for Julius and Ponticus. Conversely, there was a significant variability in protein concentration and inhibition of amylase activity. For example, the protein contents varied from $0.22 \pm 0.02 \mathrm{mg} / \mathrm{L}$ to $0.77 \pm$ $0.05 \mathrm{mg} / \mathrm{L}$ (Table 2 ) and IAA from $37.1 \pm 1.59$ to $85.3 \pm 2.5 \%$. The corresponding distribution of the proteins fraction found and their molecular weights as estimated by SDS-PAGE analysis are given in Figure S2 (Supplementary Data). 
Table 2. Doehlert design and experimental responses for optimization of ATIs extraction.

\begin{tabular}{|c|c|c|c|c|c|c|c|c|c|c|c|c|}
\hline \multirow{4}{*}{$\mathrm{Nb}$} & & & & & & & \multicolumn{6}{|c|}{ Experimental Responses } \\
\hline & \multirow{2}{*}{\multicolumn{3}{|c|}{ Coded Values }} & \multicolumn{3}{|c|}{ Real Values } & \multicolumn{3}{|c|}{ Julius } & \multicolumn{3}{|c|}{ Ponticus } \\
\hline & & & & \multirow{2}{*}{$\begin{array}{l}X_{10} \\
(\mathrm{M})\end{array}$} & \multirow{2}{*}{$\begin{array}{c}X_{6} \\
(\min )\end{array}$} & \multirow{2}{*}{$\begin{array}{c}X_{8} \\
(\mathrm{pH})\end{array}$} & \multirow{2}{*}{$\begin{array}{c}\begin{array}{c}\text { Protein } \\
\text { Concentration }\end{array} \\
(\mathrm{mg} / \mathrm{mL})\end{array}$} & \multirow{2}{*}{$\begin{array}{l}I A A \\
(\%)\end{array}$} & \multirow{2}{*}{$\begin{array}{l}I T A \\
(\%)\end{array}$} & \multirow{2}{*}{$\begin{array}{c}\begin{array}{c}\text { Protein } \\
\text { Concentration }\end{array} \\
(\mathrm{mg} / \mathrm{mL})\end{array}$} & \multirow{2}{*}{$\begin{array}{r}I A A \\
(\%)\end{array}$} & \multirow{2}{*}{$\begin{array}{l}\text { ITA } \\
(\%)\end{array}$} \\
\hline & $x_{10}$ & $x_{6}$ & $x_{8}$ & & & & & & & & & \\
\hline 1 & 0 & 0 & 0 & 1 & 105 & 8 & $0.50 \pm 0.05$ & $73.1 \pm 0.5$ & $1.6 \pm 0.6$ & $0.48 \pm 0.09$ & $60.4 \pm 3.1$ & $3.8 \pm 0.1$ \\
\hline 2 & 1 & 0 & 0 & 1.8 & 105 & 8 & $0.41 \pm 0.05$ & $82.2 \pm 4.7$ & $2.0 \pm 0.1$ & $0.32 \pm 0.02$ & $44.5 \pm 2.3$ & $2.1 \pm 0.1$ \\
\hline 3 & -1 & 0 & 0 & 0.2 & 105 & 8 & $0.58 \pm 0.02$ & $83.7 \pm 1.2$ & $3.3 \pm 0.2$ & $0.37 \pm 0.05$ & $76.3 \pm 1.0$ & $3.5 \pm 0.3$ \\
\hline 4 & 0.5 & 0.866 & 0 & 1.4 & 180 & 8 & $0.38 \pm 0.03$ & $81.0 \pm 1.5$ & $3.0 \pm 0.5$ & $0.65 \pm 0.05$ & $48.8 \pm 0.8$ & $5.8 \pm 1.0$ \\
\hline 5 & -0.5 & -0.866 & 0 & 0.6 & 30 & 8 & $0.49 \pm 0.01$ & $83.7 \pm 3.6$ & $1.8 \pm 0.0$ & $0.36 \pm 0.13$ & $49.1 \pm 0.7$ & $6.6 \pm 0.9$ \\
\hline 6 & 0.5 & -0.866 & 0 & 1.4 & 30 & 8 & $0.37 \pm 0.02$ & $84.2 \pm 3.0$ & $4.7 \pm 0.9$ & $0.77 \pm 0.15$ & $40.3 \pm 1.1$ & $7.1 \pm 1.1$ \\
\hline 7 & -0.5 & 0.866 & 0 & 0.6 & 180 & 8 & $0.53 \pm 0.03$ & $83.3 \pm 0.9$ & $2.2 \pm 0.3$ & $0.66 \pm 0.16$ & $60.9 \pm 0.1$ & $5.3 \pm 0.8$ \\
\hline 8 & 0.5 & 0.289 & 0.816 & 1.4 & 130 & 9 & $0.47 \pm 0.04$ & $75.0 \pm 1.0$ & $2.3 \pm 0.9$ & $0.49 \pm 0.02$ & $37.1 \pm 1.5$ & $6.4 \pm 0.5$ \\
\hline 9 & -0.5 & -0.289 & -0.816 & 0.6 & 80 & 7 & $0.61 \pm 0.03$ & $80.9 \pm 2.7$ & $4.0 \pm 0.2$ & $0.79 \pm 0.18$ & $72.3 \pm 1.7$ & $5.7 \pm 0.6$ \\
\hline 10 & 0.5 & -0.289 & -0.816 & 1.4 & 80 & 7 & $0.36 \pm 0.03$ & $85.3 \pm 2.5$ & $5.0 \pm 0.3$ & $0.34 \pm 0.15$ & $67.1 \pm 1.1$ & $3.5 \pm 0.2$ \\
\hline 11 & 0 & 0.577 & -0.816 & 1 & 155 & 7 & $0.52 \pm 0.02$ & $77.5 \pm 0.7$ & $4.3 \pm 0.7$ & $0.40 \pm 0.09$ & $69.4 \pm 1.2$ & $4.1 \pm 0.2$ \\
\hline 12 & -0.5 & 0.289 & 0.816 & 0.6 & 130 & 9 & $0.68 \pm 0.02$ & $82.5 \pm 1.4$ & $1.2 \pm 0.1$ & $0.58 \pm 0.05$ & $57.8 \pm 2.1$ & $3.6 \pm 0.5$ \\
\hline 13 & 0 & -0.577 & 0.816 & 1 & 55 & 9 & $0.56 \pm 0.04$ & $79.3 \pm 0.4$ & $3.0 \pm 0.2$ & $0.33 \pm 0.06$ & $42.3 \pm 2.5$ & $3.5 \pm 0.8$ \\
\hline 14 & 0 & 0 & 0 & 1 & 105 & 8 & $0.43 \pm 0.04$ & $75.4 \pm 2.1$ & $1.8 \pm 0.5$ & $0.42 \pm 0.02$ & $59.7 \pm 4.2$ & $4.4 \pm 0.4$ \\
\hline 15 & 0 & 0 & 0 & 1 & 105 & 8 & $0.51 \pm 0.05$ & $69.8 \pm 4.3$ & $2.2 \pm 0.6$ & $0.39 \pm 0.01$ & $62.2 \pm 1.9$ & $2.9 \pm 0.3$ \\
\hline 16 & 0 & 0 & 0 & 1 & 105 & 8 & $0.45 \pm 0.01$ & $73.7 \pm 0.7$ & $1.5 \pm 0.1$ & $0.43 \pm 0.09$ & $61.9 \pm 2.5$ & $3.9 \pm 0.5$ \\
\hline 17 & 0 & 0 & 0 & 1 & 105 & 8 & $0.47 \pm 0.03$ & $65.7 \pm 1.5$ & $1.3 \pm 0.1$ & $0.41 \pm 0.08$ & $58.9 \pm 2.3$ & $3.6 \pm 0.2$ \\
\hline
\end{tabular}

With, $X_{10}$ showing the concentration of sodium chloride, $X_{6}$ the extraction time and $X_{8}$ the $\mathrm{pH}$. IAA is the inhibition of amylase activity and ITA is the inhibition of trypsin activity. Each experiment was conducted in triplicate. The average values reported along with standard deviation are provided. 
The prediction models giving the correlation between parameters and experimental responses were determined and their linear, quadratic and interaction coefficients are presented in Table 3. The coefficients of determinations for the protein concentration and IAA were $0.94,0.91,0.93$ and 0.98 for Julius and Ponticus, respectively. The $\mathrm{R}^{2}$ statistic response indicates that the models as fitted are able to explain more than $90 \%$ of variability of the data. The accuracy factors, which are a qualitative term referring to measures of the relative average deviation between experimental and predicted responses were also estimated. They were 1.05 and 1.02, and 1.08 and 1.03 for Julius and Ponticus, respectively. The data shows that there was a significant correlation between different factors and experimental responses, which allowed validating the mathematical models. They were then used to represent the responses surface (Figure 2). A look at Table 3 raises the following observations: (1) Changes in salt concentration, extraction time and $\mathrm{pH}$ had a significant effect on protein concentrations, both using Julius and Ponticus ( $p$-value < 0.01). As can be seen, the increase in sodium chloride concentration resulted in a reduction in protein concentration as much with Julius as with Ponticus (Figure 2a,b). (2) Factors that had a significant effect on IAA were only observed with Ponticus, while quadratic terms affected this response with Julius. The positive sign of those quadratic factors show the registered effects were positive. These suggest that although small variations in sodium chloride concentration and extraction time at $\mathrm{pH}$ values close to 7 had an impact on the extraction process, their variations at high levels tend not to more significantly affecting the extraction of ATIs. (3) Interactions between factors did not affect the system as much, an exception for the protein concentration with Julius. This demonstrates that each parameter worked independently and that there were no synergistic effects between them. It was not obvious to expect such a result, knowing that the selective precipitation of proteins is governed by the ionic strength and that salt concentration and $\mathrm{pH}$ are together involved in solutions ionic strength. Weighted effects of extraction time, sodium chloride concentration and $\mathrm{pH}$ expressed in percent were determined and consigned in Table S3 (Supplementary Data). The general observation is that while the sum of the linear effects accounted for about $30 \%$ of the completely observed effects with Julius, it exceeded 44\% with Ponticus. Quadratic factors were almost 50\% with Julius and only half (25\%) for Ponticus. The interactions represented 21 and 31\% in Julius and Ponticus, respectively.

Table 3. Factor coefficients estimated after analysis of Doehlert design and their corresponding $\mathrm{R}^{2}$ and $A_{\mathrm{F}}$.

\begin{tabular}{|c|c|c|c|c|c|}
\hline \multirow{2}{*}{ Factors } & \multirow{2}{*}{ Coeff. } & \multicolumn{2}{|l|}{ Julius } & \multicolumn{2}{|l|}{ Ponticus } \\
\hline & & Proteins conc. $(\mathrm{mg} / \mathrm{mL})$ & IAA (\%) & Proteins conc. $(\mathrm{mg} / \mathrm{mL})$ & IAA (\%) \\
\hline \multicolumn{6}{|c|}{ Constants } \\
\hline & b0 & 0.472 & 71.5 & 0.406 & 60.6 \\
\hline \multicolumn{6}{|c|}{ Linear } \\
\hline$X_{10}$ & $b_{1}$ & $-0.071^{* *}$ & -1.0 & $-0.212 * * *$ & $-13.8^{* * *}$ \\
\hline$X_{6}$ & $b_{2}$ & $0.086^{* *}$ & -1.7 & $-0.115 *$ & $5.1^{* *}$ \\
\hline$X_{8}$ & $b_{3}$ & $0.102 * * *$ & -1.4 & $-0.149 * *$ & $-14.6^{* * *}$ \\
\hline \multicolumn{6}{|c|}{ Quadratic } \\
\hline $\begin{array}{l}X_{10}^{*} \\
X_{10}\end{array}$ & $\mathrm{~b}_{11}$ & 0.023 & $11.4^{* *}$ & 0.089 & -0.2 \\
\hline$X_{6}^{*} X_{6}$ & $b_{22}$ & -0.047 & $11.5^{* *}$ & $0.156^{*}$ & -14.4 \\
\hline$X_{8}^{*} X_{8}$ & $b_{33}$ & $0.098 * *$ & $7.1^{*}$ & 0.112 & -0.8 \\
\hline \multicolumn{6}{|c|}{ Interaction } \\
\hline$X_{10} * X_{6}$ & $b_{12}$ & -0.017 & -1.6 & $-0.208 *$ & -2.0 \\
\hline$X_{10} * X_{8}$ & $b_{13}$ & 0.031 & -6.7 & 0.049 & $-8.8 *$ \\
\hline$X_{6}^{*} X_{8}$ & $b_{23}$ & -0.039 & 3.6 & $0.356^{* *}$ & -1.1 \\
\hline$R^{2}$ & & 0.94 & 0.91 & 0.93 & 0.98 \\
\hline$A_{F}$ & & 1.05 & 1.02 & 1.08 & 1.03 \\
\hline
\end{tabular}


(a)

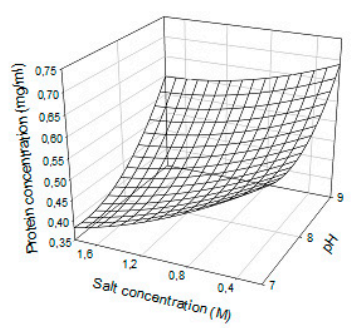

(c)

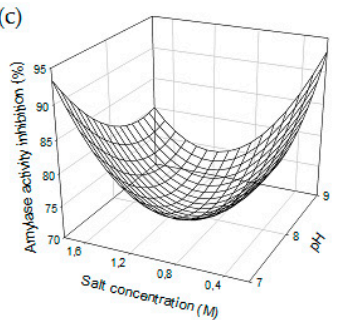

(b)

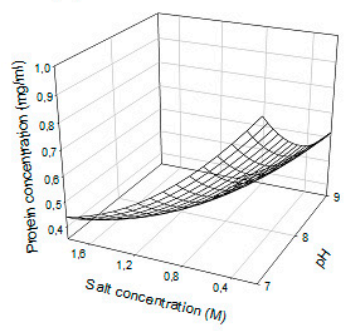

(d)

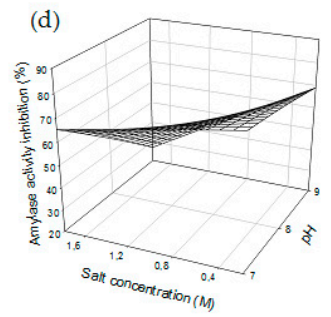

Figure 2. Response surfaces of $(\mathbf{a}, \mathbf{b})$ protein concentration and $(\mathbf{c}, \mathbf{d})$ amylase activity inhibition as function of salt concentration and $\mathrm{pH}$ with Julius and Poncticus, respectively. Extraction time is fixed at central point (105 min).

\subsubsection{Numerical Optimization}

Validated mathematical models were used to optimize the extraction process of ATIs from wheat flour. To this end, a numerical optimization was performed using the Statgraphics software (Statpoint Technologies, Inc., Warrenton, VA, USA). It was used to determine the combination of experimental parameters that simultaneously optimize responses with the best compromise. Since the results obtained with the inhibition of trypsin activity were not significant, only the results of protein concentration and IAA were processed. The goal was to minimize the protein concentration in order to precipitate the other proteins maintaining only ATIs in solution, and to maximize the inhibition of the amylase activity. Thus, solutions with maximal values of desirability of 0.94 and 0.91 were obtained for Julius and Ponticus, respectively. The optimal parameters values were: salt concentrations of 1.67 and $1.22 \mathrm{M}$, extraction times of 53 and $118 \mathrm{~min}$, and pHs of 7.1 and 7.9 for Julius and Ponticus, respectively. The corresponding responses for both wheat varieties were: protein concentrations of 0.31 and $0.35 \mathrm{mg}$ and IAAs of 91.6 and $83.3 \%$. These optimal extraction conditions were tested in triplicate and the obtained p-values were all less than 0.05 , indicating that the results were significantly different from zero at the $95.0 \%$ confidence level. The observed difference between optimal conditions with Julius and Ponticus could be due to their protein composition and therefore their ATIs composition (qualitatively and quantitatively). Dexter and Matsuo [34] showed that there is a difference in the proportion of non-gluten-related proteins (albumin and globulin) as well as a difference in the distribution of their solubility (Osborne scale) according to the wheat cultivars. In addition, growth conditions such as nitrogen, light, temperature and humidity greatly affect the differences in protein concentration between different cultivars [35].

The differences between the chromatograms obtained after ATIs fractionation of Julius and Ponticus are observed in Figures 3 and 4. Electrophoresis showed that in both cases, the extracted ATIs had a mass ranging from 10 to $20 \mathrm{kDa}$. These masses correlate with those of UniProt online database, which currently includes 13 reviewed ATIs (https://www.uniprot.org/uniprot). In addition, MALDI analysis shown that a band on the gel electrophoresis can contains several ATIs of very close molecular masses. In the case of fractions D of Julius and E of Ponticus, single protein band was obtained, that allows a separation in several closely placed mass peaks with MALDI indicating different molecular species in the single band. The extracted proteins with optimized method were thereafter digested with $\alpha$-chymotrypsin in order have a first impression of the ATIs present. The subsequent LC-MS analysis demonstrates that up to 10 ATIs can be identified (Table S5, Supplementary Data). The data 
shows a protein search summary and gives their accession numbers and numbers of the identified peptides for each protein. It also supplies the sequence coverage in each case. On basis of this primary data, further experiments are being carried out to enable quantification.

(a)

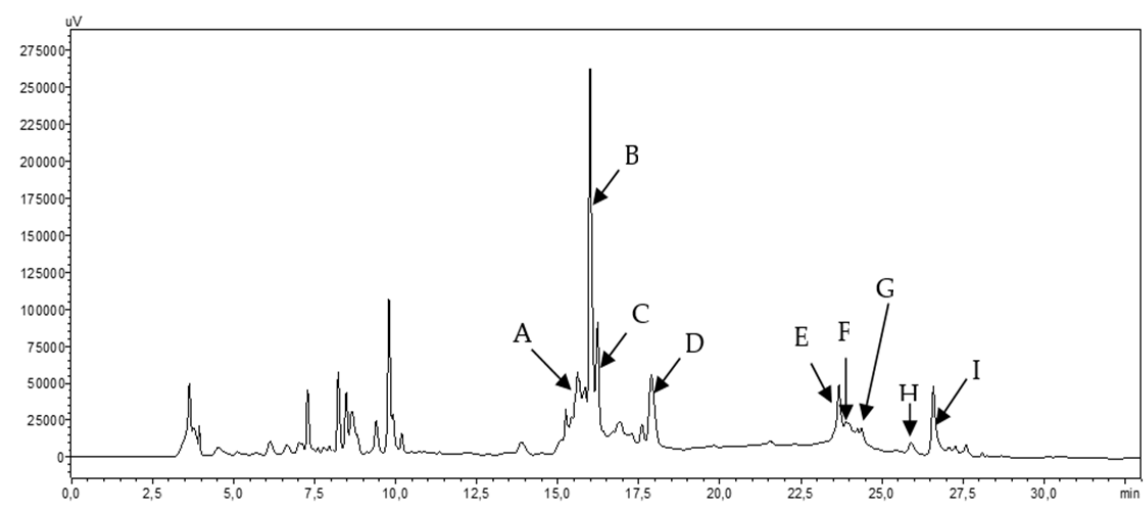

(b)

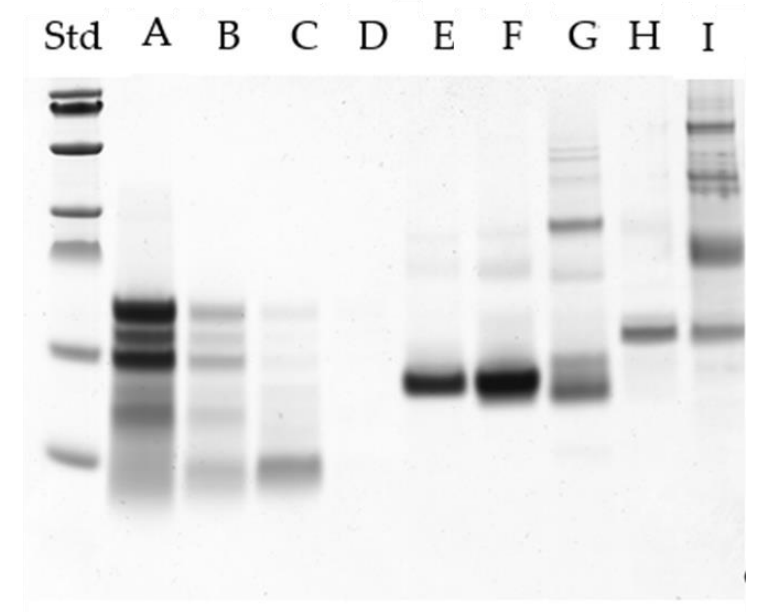

(c)
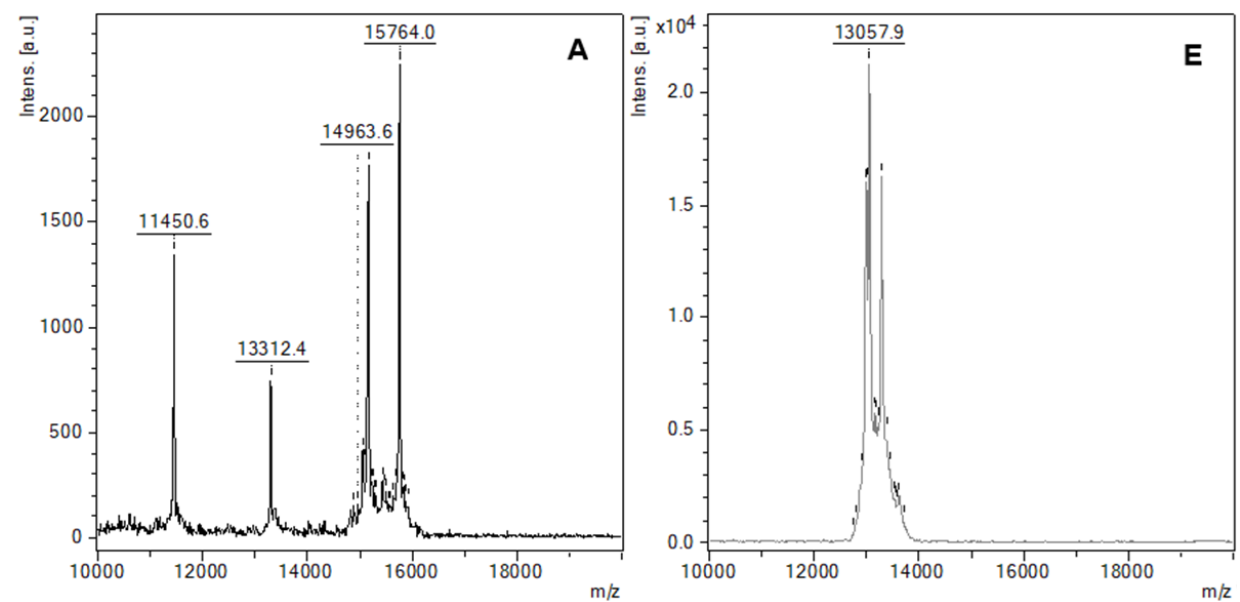

Figure 3. HPLC fractionation (a), SDS-PAGE (b) and MALDI TOF MS (c) of extracted ATIs from Ponticus. 
(a)

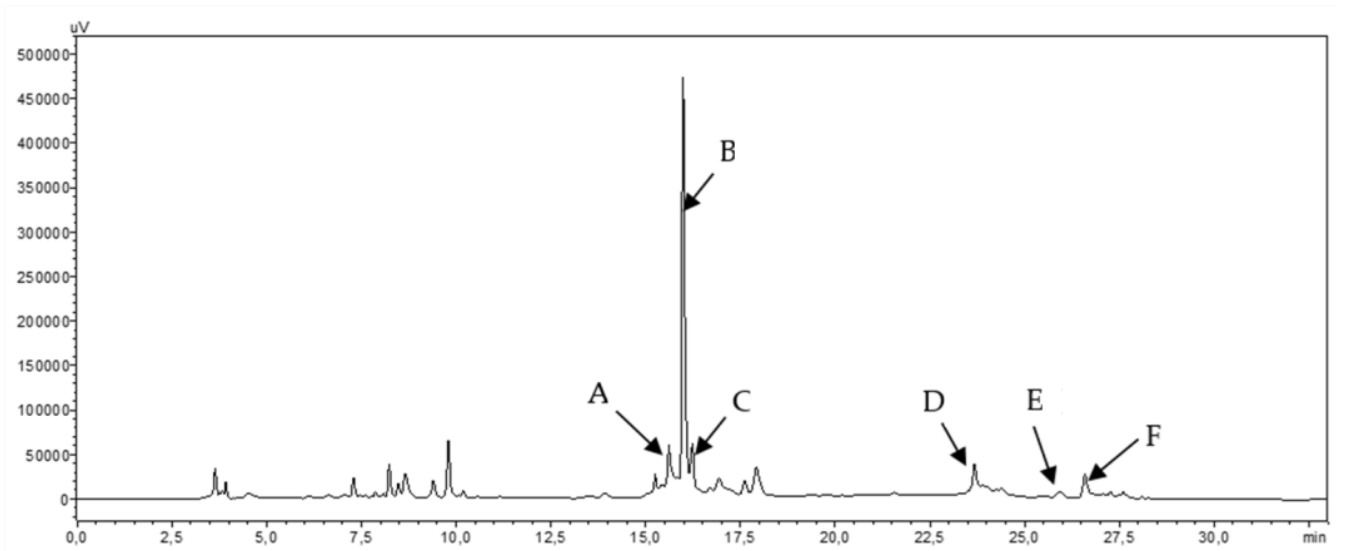

(b)
Std A B C
D $\quad$ E F

(c)
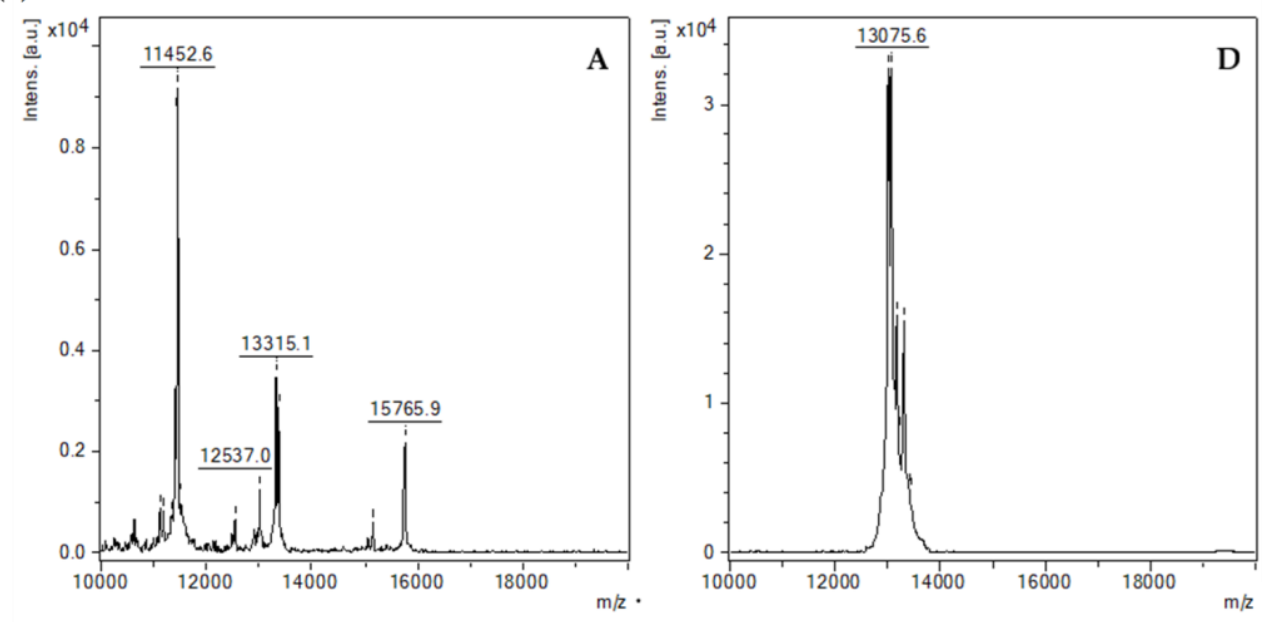

Figure 4. HPLC fractionation (a), SDS-PAGE (b) and MALDI TOF MS (c) of extracted ATIs from Julius.

\section{Materials and Methods}

\subsection{Materials}

The two soft winter varieties of wheat, Julius and Ponticus $(14.6 \%$ and $14.1 \%$ total proteins as per Kjedahl method), harvested in 2018 were received from IGV-Institut für Getreideverarbeitung 
GmbH, Nuthetal OT Bergholz-Rehbrücke, Germany. Chloroform (99.8\%), dichloromethane (99.8\%), methanol (100\%), sodium chloride and ammonium sulfate (99\%) were purchased from VWR Chemicals (Leuven, Belgium). Urea was obtained from Merck KGaA (Darmstadt, Germany). Folin \& Ciocalteu' phenol, potassium sodium tartrate tetrahydrate and maltose monohydrate $(99 \%)$ were acquired from Sigma-Aldrich (Steinheim, Germany). Tris and petroleum ether bp $30-75{ }^{\circ} \mathrm{C}$ were obtained from Carl Roth GmbH (Karlsruhe, Germany). 3,5-Dinitrosalicylic acid, 97+\% was obtained from Alfa Aesar GmbH (Karlsruhe, Germany). Iodoacetamide (IAA) (PubChem CID: 3727) as well chymotrypsin from bovine pancreas for enzymatic digestion were bought from Sigma Aldrich (St. Louis, MO, USA). Reagents and solutions were all prepared from chemicals by dilution with distilled water.

\subsection{Extraction of ATIs}

The diagram describing the different steps of ATIs extraction from wheat samples is presented in the Figure S1 (see Supplementary Data). Wheat flour $(100 \mathrm{mg}$ ) was mixed with petroleum ether $\left(0.4 \mathrm{~mL}\right.$ ) for $10 \mathrm{~min}$ at $30 \mathrm{rpm}$. After centrifugation at 10,000 $\mathrm{g}, 4^{\circ} \mathrm{C}$ for $5 \mathrm{~min}$ (centrifuge $5415 \mathrm{R}$, Eppendorf AG, Hamburg, Germany), the supernatant was removed and the precipitate was air dried at room temperature for about $20 \mathrm{~min}$. The extraction solvent was added and the whole was stirred according to the conditions derived from the experimental design. Mixture of chloroform $/ \mathrm{methanol}$ and dichloromethane/methanol with different ratios were applied. After centrifugation at $10,000 \times g$, $4{ }^{\circ} \mathrm{C}$ for $5 \mathrm{~min}$, the supernatant was fully collected and dried using a centrifugal evaporator (RC10-22, Jouan S.A., Saint-Herblain, France). Samples were redissolved in $25 \mathrm{mM}$ Tris buffer solution containing salt, and after vortex, sonication for $5 \mathrm{~min}$ and centrifugation $\left(10,000 \times \mathrm{g}, 4^{\circ} \mathrm{C}\right.$ for $\left.5 \mathrm{~min}\right)$, the supernatant containing purified ATIs (fraction with low molecular weight proteins) was carefully collected and transferred to the new micro-tubes. The precipitate containing high molecular weight protein fraction was re-dissolved in 1\% sodium dodecyl sulfate solution for analysis. Ammonium sulfate and sodium chloride were tested and different parameters were evaluated to determine the optimal conditions of the extraction process.

\subsection{Experimental Designs}

DoE combining Plackett-Burman design (PBD) and Doehlert design (DD) were used to screen and optimize the extraction process of ATIs.

\subsubsection{Plackett-Burman Design to Screen Parameters}

PBD is a two-level statistical design, which allows a rapid analysis of a large number of parameters in a minimum number of runs. It identifies with a high degree of precision the most critical parameters that significantly affect the process and those that have a negligible impact on the results. It also allows the analysis at the same time of both qualitative quantitative parameters [36]. In this study, eleven parameters were analyzed with PBD: the type of extraction solvent (X1, chloroform/methanol or dichloromethane/methanol), the composition of solvents mixture in ratio (X2, 1:1 and 2:1; volume/volume), the ratio of sample/solvent (X3, 125:1-250:1 masse/volume), the concentration of Urea $(X 4,0-50 \mathrm{mg} / \mathrm{mL})$, the extraction temperature $\left(X 5,4-25^{\circ} \mathrm{C}\right)$ and the extraction time $(X 6,60-180$ $\mathrm{min})$, stirring speed ( $\mathrm{X} 7,40-80 \mathrm{rpm})$, the buffer $\mathrm{pH}(\mathrm{X} 8, \mathrm{pH} 8-\mathrm{pH} 9)$, the type of salt (X9, ammonium sulfate and sodium chloride), the concentration of salt (X10, 0.5-1 M) and centrifugation speed (X11, 10,000-12,000 g). Preliminary studies as well as data from the literature were used to select parameters and their levels. Twelve experiments were generated (Table 1) and each experiment was made in duplicate randomly, the analysis carried out and data reported as mean \pm standard deviation.

\subsubsection{Doehlert Design}

The Doehlert design (DD) was chosen for optimization. It has a uniform distribution of experimental points and is a rotatable design with constant variance at equidistant from the central point. The experimental domain can be extended by adding new independent variables or moving the 
design to a new experimental domain [37]. DD requires a smaller number of experiments while obtaining better precision of coefficient estimates and the number of levels studied for each variable changes: five levels for the first parameter, three for the last and seven for the second in the case of a matrix with three variables [38]. Three parameters to be optimized in the DD were selected from the PBD results and their ranges of variation are described in Table S1 (supplementary data). The DD allows the description of a region around an optimal response with $n^{\wedge} 2+n+1$ points for $n$ parameters. With three parameters, seventeen experiments with four replications at the central point were generated and corresponding real values were calculated according to the coded values given by the DD (Table 2).

\subsection{High-Performance Liquid Chromatography}

The extracted ATIs were fractionated with a Shimadzu HPLC system (Shimadzu Europa GmbH, Duisburg, Germany). Solutions of $0.1 \%$ trifluoroacetic acid (TFA) and $70 \%$ acetonitrile (ACN) were used as eluent $A$ and $B$, respectively. Elution was carried out at a flow rate of $1 \mathrm{~mL} / \mathrm{min}$ and at different solvent gradients. $100 \mu \mathrm{L}$ of ATIs extracted under optimal conditions were applied to a $300 \times 4.6 \mathrm{~mm}$ PerfectSil 300 ODS C18 $5 \mu \mathrm{m}$ column (MZ Analysentechnik, Mainz, Germany). Solvent gradient during HPLC fractionation is presented in Table S2 (Supplementary data). The fractions were collected 5 times each, pooled, dried and then re-dissolved in $100 \mu \mathrm{L}$ of $25 \mathrm{mM}$ Tris buffer, $\mathrm{pH}$ 8. The re-dissolved fractions were tested for their inhibitory activity, SDS PAGE and MALDI-TOF-MS.

\subsection{Analyses}

Protein concentration, inhibition of amylase (IAA) and inhibition of trypsin (ITA) were used as experimental responses to evaluate the performance of the extraction process.

\subsubsection{Determination of Protein Concentration}

Concentration of protein was determined by the method of Lowry, et al. [39] with some modifications. Bovine serum albumin (Fluka Chemie AG, Buchs, Switzerland) was used as standard.

\subsubsection{Inhibition of Amylase Activity}

Inhibition of amylase activity was done by the DNS method [40] with modifications. The positive test was made by mixing of $10 \mu \mathrm{L}$ of $1 \mathrm{mg} / \mathrm{mL} \alpha$-amylase-specific activity of 23 units $/ \mathrm{mg}$ solid (Sigma Aldrich, Steinheim, Germany) with $190 \mu \mathrm{L}$ of $0.02 \mathrm{M}$ sodium phosphate buffer, pH 6.9 with $0.006 \mathrm{M}$ sodium chloride. The blank was prepared with $200 \mu \mathrm{L}$ of sodium phosphate buffer. After pre-incubation at $37^{\circ} \mathrm{C}$ for $3-4$ min to achieve temperature equilibration, $200 \mu \mathrm{L}$ of $1 \%$ starch solution were added and the mixture incubated for $15 \mathrm{~min}$ at $37^{\circ} \mathrm{C}$. The reaction was stopped by adding $400 \mu \mathrm{L}$ of 2,3 dinitrosalicylic acid reagent (DNS). The mixture was heated at $99^{\circ} \mathrm{C}$ for $5 \mathrm{~min}$ to develop the color, cooled down at room temperature, the total volume filled to $1.5 \mathrm{~mL}$ with $700 \mu \mathrm{l}$ of distilled water and the absorption was read at $540 \mathrm{~nm}$ with a spectrophotometer (Hanna instruments, Vöhringen, Germany). Inhibition assay was done in the same way by pre-incubating $10 \mu$ of amylase solution with $70 \mu \mathrm{l}$ of extracted ATIs and $120 \mu \mathrm{L}$ of sodium phosphate buffer at $37^{\circ} \mathrm{C}$ for $10 \mathrm{~min}$. A negative test was prepared with $70 \mu \mathrm{L}$ of ATIs and $130 \mu \mathrm{L}$ of sodium phosphate buffer. Calibration was done using maltose solutions ranging from 0.25 to $5 \mu \mathrm{mol} / \mathrm{mL}$. Residual activity was calculated and inhibition of amylase activity (IAA) expressed in percent was evaluated as described in Equation (1):

$$
I A A(\%)=\left[\left(A A_{\mathrm{C}}-A A_{\mathrm{T}}\right) / A A_{\mathrm{C}}\right] \times 100
$$

with $A A_{\mathrm{C}}$ the amylase activity of the control (without ATIs) and $A A_{\mathrm{T}}$ the tested amylase activity in presence of purified ATIs at the same conditions. 


\subsubsection{Trypsin Activity and Determination of it Inhibition}

Modified azocasein protease assay as described by Sagu, et al. [41] with some slight modifications was used to evaluate the trypsin activity inhibition. $75 \mu \mathrm{L}$ of extracted ATIs were mixed with $30 \mu \mathrm{L}$ of $0.5 \%$ sodium bicarbonate buffer $\mathrm{pH} 8.3$ and $20 \mu \mathrm{L}$ of $10 \mathrm{mg} / \mathrm{mL}$ trypsin solution (Sigma Aldrich). For the control, $20 \mu \mathrm{L}$ of trypsin were mixed with $105 \mu \mathrm{L}$ of buffer. $125 \mu \mathrm{L}$ of $2.5 \%$ azocasein solution (Sigma Aldrich) were added and the mixture was incubated at $37^{\circ} \mathrm{C}$ for $30 \mathrm{~min}$. $100 \mu \mathrm{L}$ of the mixture were mixed with $400 \mu \mathrm{L}$ of $5 \%$ trichloroacetic acid solution, incubation at room temperature for 5 min and centrifuged for $5 \mathrm{~min}$ at $10,000 \mathrm{~g}$. $400 \mu \mathrm{L}$ of the above solution were mixed with $1200 \mu \mathrm{L}$ of $500 \mathrm{mM}$ $\mathrm{NaOH}$ solution and the absorbance was taken at $440 \mathrm{~nm}$. The trypsin activity was expressed as the amount of activity that gives a change of one unit of absorbance at $440 \mathrm{~nm} / \mathrm{min}$, and the inhibition of trypsin activity (ITA) calculated in percent according to the Equation (2):

$$
\operatorname{ITA}(\%)=\left[\left(T A_{\mathrm{C}}-T A_{\mathrm{T}}\right) / T A_{\mathrm{C}}\right] \times 100
$$

where, $T A_{\mathrm{C}}$ is the trypsin activity of control and $T A_{\mathrm{T}}$ the tested trypsin activity in presence of ATIs.

\subsubsection{Electrophoresis}

Electrophoresis [42] was done under reducing and denaturing conditions using Invitrogen NuPAGE $12 \%$ Bis-Tris precast protein gels with 12 wells (Thermo Fisher Scientific, Carlsbad, CA, USA). $15 \mu \mathrm{L}$ of extracted ATIs were mixed with $15 \mu \mathrm{L}$ NuPAGETM LDS Sample Buffer $(1 \times)$ pH 8.4 containing glycerol, 2-mercaptoethanol, SDS and Coomassie blue G250. The mixture was heated at $100{ }^{\circ} \mathrm{C}$ for 5 min to denature and reduce protein disulfide bonds. After cooling to room temperature, $15 \mu \mathrm{L}$ of samples and $5 \mu \mathrm{L}$ of pre-stained broad range standard containing nine protein ladders (10, 15, 25, 35, 55, 70, 100, 130 and 250 $\mathrm{kDa}$; Thermo Fisher Scientific) were loaded in the gel and the separation was carried out under constant current (30 mA/Gel) for about $120 \mathrm{~min}$ using NuPAGE MES SDS Running Buffer $(1 \times)$. Gels were stained overnight with Coomassie brilliant blue R-250 solution and then distained with $10 \%$ acetic acid. Gels were scanned with Bio-5000 Professional VIS Gel Scanner (SERVA Electrophoresis GmbH, Heidelberg, Germany) and analyzed with Image Lab Software (Bio-Rad Laboratories Ltd., Hemel Hempstead, UK).

\subsubsection{MALDI-TOF-MS Analysis}

ATIs were analyzed for their molecular weight with a MALDI-TOF MS instrument (Autoflex Speed LRF, Bruker Daltonik GmbH, Bremen, Germany) [43]. $2 \mu \mathrm{L}$ of samples were mixed with $2 \mu \mathrm{L}$ of $2 \%$ TFA and $2 \mu \mathrm{L}$ of 2,5-Dihydroxy actetophenone (Alfa Aesar, Heysham, UK) and aliquots of $2 \mu \mathrm{L}$ were applied to the target plate (MTP target frame III, Daltonik). Protein Standard I (Bruker Daltonics) containing a mixture of four proteins was used for internal calibration and the measurements were performed in linear mode (LM).

\subsubsection{Protein Digestion and Untargeted Triple TOF/MS-Analysis}

The protein digestion is based on our former reports [44,45]. Briefly, the extracted ATIs were incubated with iodoacetamide for $20 \mathrm{~min}$ at $50{ }^{\circ} \mathrm{C}$ in the dark to alkylate cleaved disulfide bonds. The overnight-digestion at $25^{\circ} \mathrm{C}$ was initiated by adding chymotrypsin (dissolved in $1 \mathrm{mM} \mathrm{HCl}$ ) and stopped by adding $40 \%$ formic acid. To purify and isolate the peptides, a solid phase extraction using C18 cartridges (Chromabond, Machery Nagel, Düren, Germany) was performed. The columns were activated using a mixture of $50 \% \mathrm{ACN}$ and $0.1 \%$ formic acid and conditioned with triple distilled water before application of the digested extracts. After a washing step with acidified water $(0.1 \%$ formic acid) the peptides were eluted using 50\% ACN/0.1\% formic acid. The eluate was evaporated under nitrogen to achieve complete dryness and re-suspended using 50\% ACN/0.1\% formic acid and $0.1 \%$ formic acid. Untargeted peptide analysis was performed with a high resolution Triple TOF/MS system, consisting of an Eksigent micro UHPLC system (Applied Biosystems/MDS Sciex, Concord, ON, Canada), an PAL HTS-xt system auto sampler CTC Analytics (CTC Analytics, Zwingen, Switzerland) and a TripleTOF 
(C) 5600 MS/MS (AB Sciex Germany GmbH, Darmstadt, Germany). To separate the peptides a C18 analytical micro column (Halo fused C18 column, $2.7 \mu \mathrm{m}, 90 \mathrm{~A}, 0.5 \mathrm{~mm} \times 50 \mathrm{~mm}$, Eksigent) was used. Digested samples were diluted 1:100 with $0.1 \%$ formic acid. The HPLC gradient program starts with $95 \%$ solvent A $(0.1 \%$ formic acid in water) and increases after $36 \mathrm{~min}$ to $30 \%$ solvent B $(0.1 \%$ formic acid in acetonitrile), after $41 \mathrm{~min}$ to $60 \%$ and from $42 \mathrm{~min}$ to $46 \mathrm{~min}$ to $90 \%$ at a flow rate of $0.15 \mu \mathrm{L} / \mathrm{min}$ and an oven temperature of $35{ }^{\circ} \mathrm{C}$. From $47 \mathrm{~min}$ until the end of the program (51 min) the organic solvent stays at $5 \%$ for re-equilibration. Ionization was performed in positive ESI mode. Ion spray voltage was set to $5500 \mathrm{~V}$ and curtain gas (CUR) at 25 units. Full scan spectra were measured between 400 and 1200 Da. Product ion spectra were measured in IDA between 200 and 1800 Da for ions with charge state $2-5$ and which exceed 150 cps. To identify the ATIs, the acquired data was compared with 15 databank entries for Amylase Trypsin Inhibitors (organism: Triticumaestivum) in UniProtKB (http://www.uniprot.org) with the ProteinPilot software using the Paragon Algorithm. The resulting data were submitted to a False Discovery Rate-Analysis and resulted in 9 matches (FDR $<1 \%$ ).

\subsection{Statistical Analysis}

Quadratic polynomial equations with interaction between parameters were established to describe the effect of variables on experimental responses as predictive models:

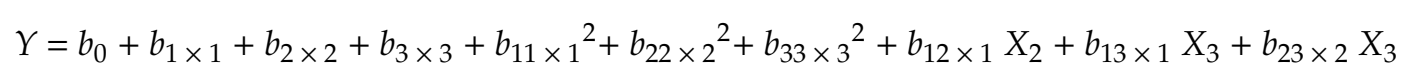

with $X_{1}, X_{2}$ and $X_{3}$ the parameters, $b_{0}$ the constant, $b_{1}, b_{2}$ and $b_{3}$ the first-order coefficients, $b_{11}, b_{22}$ and $b_{33}$ the second-order coefficients and $b_{12}, b_{13}, b_{23}$ the interaction coefficients. The least squares method was used to determine coefficients. The analysis of the variance (ANOVA) was performed and the $p$-values were calculated to evaluate the significance of the results. Effects with $p$-values less than 0.05 indicate that they are significantly different from zero at the $95.0 \%$ confidence level. Pareto chart was used to classify the parameters according to their effects. It highlights the most significant variables and facilitates the selection of those to optimize.

In addition to the coefficient of determination $\left(R^{2}\right)$, the accuracy factor $\left(A_{\mathrm{F}}\right)$ was determined in order to validate the proposed models. This analysis criterion evaluates the difference between the estimated and experimental values of the variables and was calculated as follows:

$$
A_{\mathrm{F}}=10^{(\Sigma \log \mid Y i, \mathrm{est} / Y \mathrm{i}, \exp / \mathrm{N})}
$$

where, $Y_{\mathrm{i}, \text { est }}$ is the estimated response, $Y_{\mathrm{i}, \exp }$ the experimental response and $\mathrm{N}$ the number of experiments. Generation of the experimental Designs and statistical analysis were performed with Statgraphics software (Statpoint Technologies, Inc., Warrenton, VA, USA) and the response surfaces were plotted with SigmaPlot software (Systat Software Inc., San Jose, CA, USA).

\section{Conclusions}

The salt type, salt concentration, buffer $\mathrm{pH}$ and extraction time were found to be the most important factors affecting the solubility of ATIs. Proteins were precipitated more selectively with sodium chloride than with ammonium sulfate. Chloroform and dichloromethane both produced similar results in both cultivars; therefore, dichloromethane would be a more preferable alternative while considering the negative health related effects of chloroform. Analysis of the variance showed that there was no significant interaction between the salt concentration, $\mathrm{pH}$ and extraction time during the optimization process. The wheat cultivars Julius and Ponticus presented only slightly different optimal conditions. The summarized optimal extraction parameters, as well as the corresponding inhibitory activities and protein concentrations from the two tested wheat varieties, are presented in Table S6 (Supplementary Data). These conditions therefore may also be used for other wheat cultivars. Further work is going on to this respect. The selective extraction of the $\alpha$-amylase/trypsin inhibitors is not well studied and therefore in the present manuscript a simple and optimal method 
was developed considering different aspects and factors which may influence their extractability. The positive implication of the present study lies in the quick assessment of their content in different varieties especially while scrutinizing and selecting wheat cultivars with low potential allergenic effects. HPLC allowed further fractionation and molecular weights of purified ATIs were determined by electrophoresis and MALDI-TOF-MS. Up to 10 ATIs have been identified per LC-MS out of a total of 15 reviewed and unreviewed ATIs currently listed in the Uniprot online database. In a further study, the characterization of the individual ATIs present in different cultivars with focus on their compositional quantification using targeted and untargeted proteomics tools is being envisaged.

Supplementary Materials: The following are available online, Figure S1: Extraction process of ATIs using mixtures of chloroform/methanol (C/M) or dichloromethane/methanol (D/M) as extraction solvents, Figure S2: Table S1: Protein profiles of (a) Julius extract and (b) Ponticus extract for different experimental conditions of the Doehlert design determined by SDS-PAGE, Table S1: Experimental factors and their level in Doehlert design, Table S2: Solvent gradient during HPLC fractionation, Table S3: Weighted effects of extraction time sodium chloride concentration and $\mathrm{pH}$ on experimental responses expressed in percent, Table S4: Factor coefficients estimated after analysis of Doehlert design and their corresponding $\mathrm{R}^{2}$ and $A_{f}$.

Author Contributions: Conceptualization, S.T.S., H.M.R., G.H; data analysis, S.T.S., J.B.; funding acquisition, S.T.S., methodology, S.T.S., H.M.R.; writing—original draft preparation, S.T.S.; writing-review and editing, H.M.R., G.H., T.H.

Funding: The author Sorel Sagu Tchewonpi was funded by the Alexander von Humboldt Foundation under the Georg Forster Research Fellowship (Ref 3.4-CMR-1164093-GF-P).

Acknowledgments: We thank the Institute of Cereal Processing (IGV-Institut für Getreideverarbeitung GmbH, Rehbrücke, Germany) for providing us wheat samples used in this work. We acknowledge the support of the Deutsche Forschungsgemeinschaft and Open Access Publishing Fund of University of Potsdam.

Conflicts of Interest: The authors declare no conflict of interest.

$\begin{array}{ll}\text { Abbreviations } \\ \text { ACN } & \text { Acetonitrile } \\ A_{\mathrm{F}} & \text { Accuracy factor } \\ \mathrm{AA}_{\mathrm{C}} & \text { Amylase activity of the control } \\ \mathrm{AA}_{\mathrm{T}} & \text { Tested amylase activity } \\ b_{0}, b_{1}, b_{2}, \ldots & \text { Coefficients of models } \\ \text { ATIs } & \alpha \text {-amylase/trypsin inhibitors } \\ \text { C/M } & \text { Chloroform/methanol mixture } \\ \text { D/M } & \text { Dichloromethane/methanol mixture } \\ \text { DD } & \text { Doehlert design } \\ \text { DNS } & \text { Dinitrosalicylic acid color reagent } \\ \text { DoE } & \text { Design of experiment } \\ \text { IAA } & \text { Inhibition of amylase activity } \\ \text { ITA } & \text { Inhibition of trypsin activity } \\ \text { LM } & \text { Linear mode } \\ \text { M } & \text { Molarity } \\ \text { MALDI-TOF } & \text { Matrix Assisted Laser Desorption Ionization-Time of Flight } \\ \text { MS } & \text { Mass Spectrometry } \\ N & \text { Number of parameters } \\ p & \text { Probability } \\ \text { PBD } & \text { Plackett - Burman design } \\ \text { SDS } & \text { Sodium dodecyl sulfate } \\ X_{1} X_{2}, X_{3} & \text { Parameters } \\ \text { TA } & \text { Trypsin activity of control } \\ \text { TA } & \text { Tested trypsin activity } \\ \text { TFA } & \text { Trifluoroacetic } \\ Y & \text { Experimental response } \\ 2,5-D H A P & \text { 2,5-Dihydroxy actetophenone } \\ & \end{array}$




\section{References}

1. Makela, M.J.; Eriksson, C.; Kotaniemi-Syrjanen, A.; Palosuo, K.; Marsh, J.; Borres, M.; Kuitunen, M.; Pelkonen, A.S. Wheat allergy in children-new tools for diagnostics. Clin. Exp. Allergy 2014, 44, 1420-1430. [CrossRef] [PubMed]

2. Young, E.; Stoneham, M.D.; Petruckevitch, A.; Barton, J.; Rona, R. A population study of food intolerance. Lancet 1994, 343, 1127-1130. [CrossRef]

3. Jin, Y.; Acharya, H.G.; Acharya, D.; Jorgensen, R.; Gao, H.; Secord, J.; Ng, P.K.W.; Gangur, V. Advances in Molecular Mechanisms of Wheat Allergenicity in Animal Models: A Comprehensive Review. Molecules 2019, 24, 1142. [CrossRef] [PubMed]

4. Verhoeckx, K.C.M.; Vissers, Y.M.; Baumert, J.L.; Faludi, R.; Feys, M.; Flanagan, S.; Herouet-Guicheney, C.; Holzhauser, T.; Shimojo, R.; van der Bolt, N.; et al. Food processing and allergenicity. Food Chem. Toxicol. 2015, 80, 223-240. [CrossRef] [PubMed]

5. Berin, M.C.; Sampson, H.A. Mucosal immunology of food allergy. Curr. Biol. 2013, 23, R389-R400. [CrossRef]

6. Bathrellou, E.; Kontogianni, M.D.; Panagiotakos, D.B. Celiac disease and non-celiac gluten or wheat sensitivity and health in later life: A review. Maturitas 2018, 112, 29-33. [CrossRef]

7. Talley, N.J.; Walker, M.M. Celiac Disease and Nonceliac Gluten or Wheat Sensitivity: The Risks and Benefits of Diagnosis. JAMA Intern. Med. 2017, 177, 615-616. [CrossRef]

8. Catassi, C.; Bai, J.C.; Bonaz, B.; Bouma, G.; Calabro, A.; Carroccio, A.; Castillejo, G.; Ciacci, C.; Cristofori, F.; Dolinsek, J.; et al. Non-Celiac Gluten sensitivity: The new frontier of gluten related disorders. Nutrients 2013, 5, 3839-3853. [CrossRef]

9. Jang, Y.R.; Beom, H.R.; Altenbach, S.B.; Lee, M.K.; Lim, S.H.; Lee, J.Y. Improved Method for Reliable HMW-GS Identification by RP-HPLC and SDS-PAGE in Common Wheat Cultivars. Molecules 2017, 22, 1055. [CrossRef]

10. Franco, O.L.; Rigden, D.J.; Melo, F.R.; Bloch, C., Jr.; Silva, C.P.; Grossi de Sa, M.F. Activity of wheat alpha-amylase inhibitors towards bruchid alpha-amylases and structural explanation of observed specificities. Eur. J. Biochem. 2000, 267, 2166-2173. [CrossRef]

11. Oda, Y.; Matsunaga, T.; Fukuyama, K.; Miyazaki, T.; Morimoto, T. Tertiary and quaternary structures of 0.19 alpha-amylase inhibitor from wheat kernel determined by X-ray analysis at $2.06 \mathrm{~A}$ resolution. Biochemistry 1997, 36, 13503-13511. [CrossRef] [PubMed]

12. Feng, G.H.; Richardson, M.; Chen, M.S.; Kramer, K.J.; Morgan, T.D.; Reeck, G.R. alpha-Amylase inhibitors from wheat: Amino acid sequences and patterns of inhibition of insect and human alpha-amylases. Insect. Biochem. Mol. Biol 1996, 26, 419-426. [CrossRef]

13. Prandi, B.; Faccini, A.; Tedeschi, T.; Galaverna, G.; Sforza, S. LC/MS analysis of proteolytic peptides in wheat extracts for determining the content of the allergen amylase/trypsin inhibitor CM3: Influence of growing area and variety. Food Chem. 2013, 140, 141-146. [CrossRef]

14. Zevallos, V.F.; Raker, V.; Tenzer, S.; Jimenez-Calvente, C.; Ashfaq-Khan, M.; Russel, N.; Pickert, G.; Schild, H.; Steinbrink, K.; Schuppan, D. Nutritional Wheat Amylase-Trypsin Inhibitors Promote Intestinal Inflammation via Activation of Myeloid Cells. Gastroenterology 2017, 152, 1100-1113.e1112. [CrossRef]

15. Alves, T.O.; D'Almeida, C.T.S.; Victorio, V.C.M.; Souza, G.H.M.F.; Cameron, L.C.; Ferreira, M.S.L. Immunogenic and allergenic profile of wheat flours from different technological qualities revealed by ion mobility mass spectrometry. J. Food Comp. Analy. 2018, 73, 67-75. [CrossRef]

16. Sotkovsky, P.; Sklenar, J.; Halada, P.; Cinova, J.; Setinova, I.; Kainarova, A.; Golias, J.; Pavlaskova, K.; Honzova, S.; Tuckova, L. A new approach to the isolation and characterization of wheat flour allergens. Clin. Exp. Allergy 2011, 41, 1031-1043. [CrossRef]

17. Altenbach, S.B.; Vensel, W.H.; Dupont, F.M. The spectrum of low molecular weight alpha-amylase/protease inhibitor genes expressed in the US bread wheat cultivar Butte 86. BMC Res. Notes 2011, 4, 242. [CrossRef]

18. Gomez, L.; Martin, E.; Hernandez, D.; Sanchez-Monge, R.; Barber, D.; del Pozo, V.; de Andres, B.; Armentia, A.; Lahoz, C.; Salcedo, G.; et al. Members of the alpha-amylase inhibitors family from wheat endosperm are major allergens associated with baker's asthma. FEBS Lett. 1990, 261, 85-88. [CrossRef]

19. Geisslitz, S.; Ludwig, C.; Scherf, K.A.; Koehler, P. Targeted LC-MS/MS Reveals Similar Contents of alpha-Amylase/Trypsin-Inhibitors as Putative Triggers of Nonceliac Gluten Sensitivity in All Wheat Species except Einkorn. J. Agric. Food Chem. 2018, 66, 12395-12403. [CrossRef] 
20. Tundo, S.; Lupi, R.; Lafond, M.; Giardina, T.; Larre, C.; Denery-Papini, S.; Morisset, M.; Kalunke, R.; Sestili, F.; Masci, S. Wheat ATI CM3, CM16 and 0.28 Allergens Produced in Pichia Pastoris Display a Different Eliciting Potential in Food Allergy to Wheat (double dagger). Plants 2018, 7, 101. [CrossRef]

21. Moller, J.; Schroer, M.A.; Erlkamp, M.; Grobelny, S.; Paulus, M.; Tiemeyer, S.; Wirkert, F.J.; Tolan, M.; Winter, R. The effect of ionic strength, temperature, and pressure on the interaction potential of dense protein solutions: From nonlinear pressure response to protein crystallization. Biophys. J. 2012, 102, 2641-2648. [CrossRef] [PubMed]

22. Wagner, J.R.; Mount, E.M.; Giles, H.F. Design of Experiments. In Extrusion (Second Edition); Wagner, J.R., Mount, E.M., Giles, H.F., Eds.; William Andrew Publishing: Oxford, UK, 2014; pp. 291-308.

23. Drouillard, K.G.; Hagen, H.; Haffner, G.D. Evaluation of chloroform/methanol and dichloromethane/hexane extractable lipids as surrogate measures of sample partition capacity for organochlorines in fish tissues. Chemosphere 2004, 55, 395-400. [CrossRef] [PubMed]

24. Cequier-Sanchez, E.; Rodriguez, C.; Ravelo, A.G.; Zarate, R. Dichloromethane as a solvent for lipid extraction and assessment of lipid classes and fatty acids from samples of different natures. J. Agric. Food Chem. 2008, 56, 4297-4303. [CrossRef] [PubMed]

25. Vertommen, A.; Panis, B.; Swennen, R.; Carpentier, S.C. Evaluation of chloroform/methanol extraction to facilitate the study of membrane proteins of non-model plants. Planta 2010, 231, 1113-1125. [CrossRef] [PubMed]

26. Salcedo, G.; Rodriguezloperena, M.A.; Aragoncillo, C. Relationships among Low Mw Hydrophobic Proteins from Wheat Endosperm. Phytochemistry 1978, 17, 1491-1494. [CrossRef]

27. Guinn, E.J.; Pegram, L.M.; Capp, M.W.; Pollock, M.N.; Record, M.T., Jr. Quantifying why urea is a protein denaturant, whereas glycine betaine is a protein stabilizer. Proc. Natl. Acad. Sci. USA 2011, 108, 16932-16937. [CrossRef]

28. Felitsky, D.J.; Record, M.T., Jr. Thermal and urea-induced unfolding of the marginally stable lac repressor DNA-binding domain: A model system for analysis of solute effects on protein processes. Biochemistry 2003, 42, 2202-2217. [CrossRef]

29. Whitney, P.L.; Tanford, C. Solubility of amino acids in aqueous urea solutions and its implications for the denaturation of proteins by urea. J. Biol. Chem. 1962, 237, 1735-1737.

30. Leberman, R. The Hofmeister series and ionic strength. FEBS Lett. 1991, 284, 293-294. [CrossRef]

31. Calzone, F.J.; Angerer, R.C.; Gorovsky, M.A. Regulation of protein synthesis in Tetrahymena: Isolation and characterization of polysomes by gel filtration and precipitation at $\mathrm{pH}$ 5.3. Nucl. Acids Res. 1982, 10, 2145-2161. [CrossRef]

32. Maity, H.; Karkaria, C.; Davagnino, J. Mapping of solution components, $\mathrm{pH}$ changes, protein stability and the elimination of protein precipitation during freeze-thawing of fibroblast growth factor 20. Int. J. Pharm. 2009, 378, 122-135. [CrossRef] [PubMed]

33. Henning, A.K.; Albrecht, D.; Riedel, K.; Mettenleiter, T.C.; Karger, A. An alternative method for serum protein depletion/enrichment by precipitation at mildly acidic $\mathrm{pH}$ values and low ionic strength. Proteomics 2015, 15, 1935-1940. [CrossRef] [PubMed]

34. Dexter, J.E.; Matsuo, R.R. Influence of Protein Content on Some Durum Wheat Quality Parameters. Canadian J. Plant Sci. 1977, 57, 717-727. [CrossRef]

35. Terman, G.L. Yields and Protein Content of Wheat Grain as Affected by Cultivar, N, and Environmental Growth Factors1. Agronomy J. 1979, 71, 437. [CrossRef]

36. Plackett, R.L.; Burman, J.P. The Design of Optimum Multifactorial Experiments. Biometrika 1946, 33, 305-325. [CrossRef]

37. Pinkowska, H.; Krzywonos, M.; Wolak, P.; Zlocinska, A. Pectin and Neutral Monosaccharides Production during the Simultaneous Hydrothermal Extraction of Waste Biomass from Refining of Sugar-Optimization with the Use of Doehlert Design. Molecules 2019, 24, 472. [CrossRef] [PubMed]

38. Fauduet, H.; Porte, C.; Havet, J.L.; Daguet, D. Modelling of influential parameters on a continuous evaporation process by Doehlert shells. J. Autom. Methods Manag. Chem. 2003, 25, 21-30. [CrossRef]

39. Lowry, O.H.; Rosebrough, N.J.; Farr, A.L.; Randall, R.J. Protein measurement with the Folin phenol reagent. J. Biol. Chem. 1951, 193, 265-275. [PubMed]

40. Bernfeld, P. Amylases, $\alpha$ and $\beta$. In Methods in Enzymology; Academic Press: Cambridge, MA, USA, 1955; Volume 1, pp. 149-158. 
41. Sagu, S.T.; Nso, E.J.; Homann, T.; Kapseu, C.; Rawel, H.M. Extraction and purification of beta-amylase from stems of Abrus precatorius by three phase partitioning. Food Chem. 2015, 183, 144-153. [CrossRef]

42. Laemmli, U.K. Cleavage of Structural Proteins during the Assembly of the Head of Bacteriophage T4. Nature 1970, 227, 680-685. [CrossRef]

43. Ali, M.; Homann, T.; Khalil, M.; Kruse, H.P.; Rawel, H. Milk whey protein modification by coffee-specific phenolics: Effect on structural and functional properties. J. Agric. Food Chem. 2013, 61, 6911-6920. [CrossRef] [PubMed]

44. Huschek, G.; Bonick, J.; Merkel, D.; Huschek, D.; Rawel, H. Authentication of leguminous-based products by targeted biomarkers using high resolution time of flight mass spectrometry. Lwt-Food Sci. Technol. 2018, 90, 164-171. [CrossRef]

45. Bonick, J.; Huschek, G.; Rawel, H.M. Determination of wheat, rye and spelt authenticity in bread by targeted peptide biomarkers. J. Food Comp. Analy. 2017, 58, 82-91. [CrossRef]

Sample Availability: Samples are available from the authors.

(C) 2019 by the authors. Licensee MDPI, Basel, Switzerland. This article is an open access article distributed under the terms and conditions of the Creative Commons Attribution (CC BY) license (http://creativecommons.org/licenses/by/4.0/). 